\title{
Transcutaneous Vagus Nerve Stimulation (tVNS) for headache prophylaxis: initial experience
}

\author{
D Magis ${ }^{*}$, P Gérard, J Schoenen \\ From The European Headache and Migraine Trust International Congress \\ London, UK. 20-23 September 2012
}

\begin{abstract}
Introduction
Neurostimulation is of increasing interest in headache therapy. Invasive neurostimulation methods were found effective in drug-refractory headaches. There is a need for non invasive therapies that could be justified in less disabled patients. Previous case reports suggested that internal Vagus Nerve Stimulation (VNS) might be effective in headache prevention [1-3].
\end{abstract}

\section{Objectives}

We explored efficacy and safety of a transcutaneous VNS device (tVNS, Gammacore ${ }^{\circledR}$ ) as preventive treatment in primary headache sufferers. The aim of this pilot trial was to determine a target subpopulation for a multicenter sham-controlled study.

\section{Methods}

Eighteen patients accepted to undertake prophylaxis with tVNS: 12 migraine without aura patients (MO, 5 with medication overuse, $\mathrm{MOH}, 3$ chronic), 4 patients with trigeminal autonomic cephalalgia (2 chronic cluster headache, $\mathrm{CCH}$ ), and 2 with hemicrania continua $(\mathrm{HC})$. tVNS was applied 3 times/day during 90 seconds. Data were collected using headache diaries.

\section{Results}

Results are available for 13 patients. Ten patients stopped tVNS after 0.7 to 6 weeks because of lack of efficacy $(\mathrm{N}=9)$ and/or side effects $(\mathrm{N}=6)$. In one patient with $\mathrm{CCH}$, attacks decreased from $4.5 /$ day to $0.39 /$ day, and in a patient with $\mathrm{MOH}$ headache days decreased from $7 /$ week to $3 /$ week and intensity from 8.5 to $4 / 10$. The benefit remains after 5 months of treatment and attack frequency increases when stimulation is interrupted. The last patient had $\mathrm{HC}$ with initial intensity decrease from 8.5 to $4 / 10$ but relapsed after 8 weeks. Reported side effects were local discomfort $(\mathrm{N}=3)$, tonic muscle contraction $(\mathrm{N}=3)$, fatigue $(\mathrm{N}=1)$, palpitations $(\mathrm{N}=1)$ and cervical muscle spasm $(\mathrm{N}=1)$.

\section{Conclusions}

Our initial experience suggests that tVNS might help some headache patients. That it was not effective in many patients may be due to the fact that the vagus nerve is not or insufficiently stimulated. There were no serious adverse events but the stimulation could be poorly tolerated.

Published: 21 February 2013

\section{References}

1. Sadler RM, Purdy RA, Rahey S: Vagal nerve stimulation aborts migraine in patient with intractable epilepsy. Cephalalgia 2002, 22(6):482-4.

2. Hord ED, Evans MS, Mueed S, Adamolekun B, Naritoku DK: The effect of vagus nerve stimulation on migraines. The journal of pain : official journal of the American Pain Society 2003, 4(9):530-4.

3. Mauskop A: Vagus nerve stimulation relieves chronic refractory migraine and cluster headaches. Cephalalgia 2005, 25(2):82-86.

doi:10.1186/1129-2377-14-S1-P198

Cite this article as: Magis et al:: Transcutaneous Vagus Nerve

Stimulation (tVNS) for headache prophylaxis: initial experience. The Journal of Headache and Pain 2013 14(Suppl 1):P198.

Submit your manuscript to a SpringerOpen ${ }^{\mathcal{O}}$ journal and benefit from:

- Convenient online submission

- Rigorous peer review

- Immediate publication on acceptance

- Open access: articles freely available online

- High visibility within the field

- Retaining the copyright to your article

Submit your next manuscript at $>$ springeropen.com

University Department of Neurology, Belgium

(C) 2013 Magis et al; licensee Springer. This is an Open Access article distributed under the terms of the Creative Commons Attribution License (http://creativecommons.org/licenses/by/2.0), which permits unrestricted use, distribution, and reproduction in any medium, provided the original work is properly cited. 